\title{
First Report of Krymsk 5 (cv. VSL 2) Cherry Rootstock In Vitro Propagation: Studying the Effect of Cytokinins, Auxins and Endogenous Sugars
}

\author{
Athanasios TSAFOUROS*, Peter A. ROUSSOS \\ Agricultural University of Athens, Department of Crop Science, Laboratory of Pomology, Iera Odos 75, Athens 118 55, \\ Greece; thantsaf@hotmail.com ("correspondingauthor); roussosp@aua.gr
}

\begin{abstract}
Krymsk $^{\circ} 5$ (VSL-2) is a semi-dwarf cherry rootstock adaptable to a range of climates. The present study aimed to establish the first efficient in vitro propagation protocol for this rootstock. Therefore, six cytokinines, four adenine type (6benzyladenine, 2-isopentenyladenine, kinetin and meta-topolin) and two phenylureas (thidiazuron and forchlorfenuron) at three $(2.4 \mu \mathrm{M}, 4.8 \mu \mathrm{M}$ and $9.6 \mu \mathrm{M})$ concentrations plus three $(0.24 \mu \mathrm{M}, 0.48 \mu \mathrm{M}, 0.96 \mu \mathrm{M})$ for thidiazuron only were tested during the multiplication stage. 6-Benzyladenine was the most efficient cytokinin, based on the number of shoots produced (3.5 shoots at $9.6 \mu \mathrm{M})$ and the number of nodes per explant $(10$ nodes at $9.6 \mu \mathrm{M})$ whereas the other aromatic adenine tested, i.e. meta-topolin, presented the highest number of nodes per $\mathrm{cm}$ and node per shoot. During the rooting stage the synthetic auxins 1-naphthaleneacetic acid (1-NAA) and indolebutyric acid (IBA) were tested at concentrations of $0,2.5,5,10$ and 20 $\mu \mathrm{M}$ both separately and in all possible combinations. The percentage of successfully rooted explants reached $95 \%$ under the combination of $20 \mu \mathrm{M}$ IBA plus $5 \mu \mathrm{M}$ 1-NAA, whereas the highest number of roots recorded was 8.5 roots for the treatment $20 \mu \mathrm{M}$ IBA plus $2.5 \mu \mathrm{M}$ 1-NAA. Furthermore, two different carbon sources were compared, the widely used sucrose and the endogenous sugar ratio of mother plant softwood shoot, sampled during late of May. Endogenous sugar ratio proved to be the preferable carbon source, since it increased the number of shoots produced and almost doubled the number of produced nodes per explant.
\end{abstract}

Keywords: benzyladenine; carbohydrates; furfuryladenine; metaTopolin, micropropagation; Prunus

Abbreviations: 1-NAA: 1-Naphthalene acetic acid; 2iP: 2-isopentenyladenine; BA: 6-Benzyladenine; CPPU: Forchlorfenuron; DKW: Driver and Kuniyuki Walnut medium; $\mathrm{GA}_{3}$ : Gibberellic acid; IBA: Indole-3-butyric acid; Kin Kinetin: mTop meta-Topolin; SSR: Sorbitol to Sucrose Ratio; TDZ: Thidiazuron; Z: Zeatin

\section{Introduction}

Rootstocks are widely used in agricultural practise in many species (such as plum, peach, pear etc.) for their special properties and characteristics (Webster, 1993). Vigor, yield precocity, adaptation to soil and environmental conditions and resistance to biotic agents are some of the traits evaluated during the development of a new cherry rootstock (Webster, 1993). Krymsk 5 synonym VSL-2 (Prunus fruticosa $\times$ Prunus lannesiana) is a relatively newly released cherry rootstock. It is characterized as a semi-dwarf rootstock as it reduces trees reaching $85-90 \%$ of the size on Mazzard rootstock (Long and Kaiser, 2010). Maas et al. (2014) working with cv. 'Kordia' grafted on Krymsk 5 and GiSelA $^{\circ} 5$ rootstocks concluded that fruit production per tree, flowering intensity, shoot growth and trunk diameter was not significantly affected by the rootstock used. Krymsk $^{\circ} 5$ is better adapted in heavy soils than 'Mazzard' and is well adapted in both cold and hot climates without leaf cupping as happens to $\mathrm{GiSelA}^{\circ} 5$ in high temperatures (Long and Kaiser, 2010).

Micropropagation allows the rapid clonal propagation of plant species in limited time and space and is widely used in propagating elite Prunus species of an economical and scientific interest including cherry rootstocks and cultivars (Godoy et al., 2017).

Multiple factors affect micropropagation rates, such as the ingredients of a medium and most significantly the plant growth regulators used, as well as their concentration and combinations (George et al., 2008). The major plant growth regulators used in in vitro propagation are auxins, mainly during the rooting stage and cytokinins during the multiplication stage (De Klerk et al., 1997; Yancheva and 
Kondakova, 2016). The most widely used cytokines are zeatin (Z), 6-benzylaminopurine (BA), kinetin (Kin), and 2-isopentenyladenine (2iP) (Yancheva and Kondakova, 2016), whereas forchlorfenuron (CPPU) (Caboni et al., 2009) as well as thidiazuron (TDZ) have been reported to have cytokinin-like action (Yancheva and Kondakova, 2016). Meta-Topolin (mTop), a natural aromatic cytokinin, has also been used in in vitro propagation of various species (Wojtania, 2010; Monticelli et al., 2017). Gibberelins (especially gibberelic acid, $\mathrm{GA}_{3}$ ) (Gonbad et al., 2014) and synthetic auxins (1-naphthaleneacetic acid, 1NAA or indolebutyric acid, IBA) (Doric et al., 2014) have been utilized in combination with BA with satisfactory results during the multiplication stage of some Rosaceae and other species and hybrids, resulting in many cases in significantly better results than BA alone (D'Angeli $e t$ al., 2001; Kadota et al., 2001; Andreu and Marın, 2005; Dejampour et al., 2011; Sadeghi et al., 2015; Akhtar et al., 2016).

The effect of the carbon source has been also studied in in vitro culture (Nowak et al., 2004; Fotopoulos and Sotiropoulos, 2004; Nacheva and Gercheva, 2009) as it plays a crucial role in the successful propagation. Even though sucrose is the most used sugar in in vitro cultivation (George et al., 2008), other carbohydrates have also been used, resulting in better propagation rates than sucrose (Roussos and Pontikis, 2002). These carbohydrates are in most cases the major carbohydrate of the specific species, justifying partly their superiority in in vitro culture. According to Hammatt (1993) the supplementation of growth medium with the carbohydrates found in plant phloem sap could probably be a better carbon source, giving superior results, than the use of sucrose alone.

To our knowledge, this is the first report on the in vitro propagation of the cherry rootstock Krymsk 5 . The aim of this study was to establish an efficient in vitro propagation protocol by studying the effect of six cytokinines [four adenines (6-benzyladenine, 2-isopentenyladenine, kinetin and meta-topolin) and two phenylureas (thidiazuron and forchlorfenuron)] during the multiplication stage and two auxins (IBA and 1-NAA) during the rooting stage. Furthermore, in order to assess the effect of carbon source on in vitro propagation rate, sucrose as well as a combination of endogenously found sugars was also studied.

\section{Materials and Methods}

\section{Endogenous carbohydrates analysis}

Krymsk $^{\circ} 5$ mother plants were maintained at the rootstocks collection of Agricultural University of Athens. Shoot samples from 4 years old trees were collected during late May, a period of fast shoot elongation, transferred to the Laboratory of Pomology under low temperature and placed in a freezer. The samples were lyophilized, ground into fine powder and stored in a freezer $\left(-25^{\circ} \mathrm{C}\right)$ till analysis. For sugar extraction, $50 \mathrm{mg}$ d.w. of sample was extracted with $2.5 \mathrm{ml}$ of HPLC water in a microwave oven at 400 watt for $1.5 \mathrm{~min}$, according to Denaxa et al. (2012). The sample was cooled and then centrifuged at $4000 \mathrm{~g}$ for $6 \mathrm{~min}$. The supernatant was collected and the pellet was re- extracted with water, following the same procedures. The two supernatants were combined, filtered through a nylon syringe filter $(0.45 \mu \mathrm{m}$ pores $)$ and analyzed by HPLC. The analysis was conducted using a Waters 510 isocratic pump running at $0.6 \mathrm{ml} \mathrm{min}^{-1}$ with a Hamilton HC-75 cation exchange column, calcium form $\left(\mathrm{Ca}^{2+}\right)$ (Hamilton, Bonaduz, Switzerland). The mobile phase consisted of HPLC grade water whereas column was equilibrated at 80 ${ }^{\circ} \mathrm{C}$. Sugars were detected with an HP $1047 \mathrm{~A}$ refractive index detector and quantified using a five point calibration curve $\left(y=25.25 x, R^{2}=0.998\right.$ for sucrose; $y=37.16 x$, $\mathrm{R}^{2}=0.994$ for fructose; $\mathrm{y}=42.157 \mathrm{x}, \mathrm{R}^{2}=0.998$ for glucose, $y=48.388 x, R^{2}=0.999$ for sorbitol) obtained by known external standards. The endogenous sugar ratio was estimated using at least five shoot samples. Sorbitol:Sucrose ratio (SSR) ratio was estimated as the ratio of endogenous sorbitol and sucrose content.

\section{Explant source and in vitro establishment}

Nodal segments (approximately $2 \mathrm{~cm}$ ) were excised from mother plant softwood shoots collected early in summer. The segments were firstly washed with running tap water to remove any residues. Sterilization comprised the use of $75 \% \mathrm{v} / \mathrm{v}$ ethanol for 13 seconds followed by a period of 15 minutes in 13\% v/v sodium hypochlorite low in bromide, plus 2-3 drops of Tween 20 . The explants were washed thrice with sterilized deionized water to remove any traces of the disinfectant.

After sterilization, the explants were planted in test tubes containing $10 \mathrm{ml}$ of Driver and Kuniyuki Walnut medium (DKW), supplemented with $9 \mathrm{~g} \mathrm{~L}^{-1}$ Agar, $30 \mathrm{~g} \mathrm{~L}^{-1}$ sucrose, $4.8 \mu \mathrm{M}$ BA, $0.7 \mu \mathrm{M} \mathrm{GA}_{3}$ and $0.5 \mu \mathrm{M}$ 1-NAA. The $\mathrm{pH}$ was adjusted at 5.8 (prior autoclaving). After a period of four weeks the produced shoots were excised and transplanted for eight weeks, in a same, fresh substrate in order to increase the number of explants. All explants were cultured under $22 \pm 1{ }^{\circ} \mathrm{C}$, 16h of photoperiod and light intensity of 3000 lux provided by cool daylight fluorescent lamps.

\section{Effect of cytokinin type and carbon source on explant multiplication rate}

In order to assess the effect of carbon source on in vitro performance of $\mathrm{Krymsk}^{\circ} 5$ explants, microshoots of approximately $1 \mathrm{~cm}$ were transplanted in DKW substrate supplemented with $4.8 \mu \mathrm{M} \mathrm{BA}, 0.7 \mu \mathrm{M} \mathrm{GA}_{3}$ and $0.5 \mu \mathrm{M} 1$ NAA, containing either a) sucrose $\left(30 \mathrm{~g} \mathrm{~L}^{-1}\right)$ as source of carbon, which served as control treatment, or b) a mixture of endogenously found carbohydrates at a ratio of $2.4 \mathrm{~g} \mathrm{~L}^{-1}$ sucrose, $2.4 \mathrm{~g} \mathrm{~L}^{-1}$ fructose, $5.2 \mathrm{~g} \mathrm{~L}^{-1}$, glucose and $20 \mathrm{~g} \mathrm{~L}^{-1}$ sorbitol. The explants remained at these media for eight weeks, after which the number of shoots, their length and the number of nodes were measured.

A second experiment took place, in order to assess the efficacy of six different cytokinins on in vitro multiplication rate. Treatments consisted of three concentrations of each cytokinin, except from TDZ where six concentrations were assessed. More specifically, the following cytokinins BA, Kin, 2iP, mTop, CPPU and TDZ were applied at concentrations of $2.4,4.8$ and $9.6 \mu \mathrm{M}$, whereas TDZ was also tested at lower concentrations i.e. $0.24,0.48$ and 0.96 . 
154

mTop and CPPU were filter sterilized, while the rest of cytokinins were autoclaved. The substrate was supplied with the endogenous sugar ratio as indicated by the HPLC analysis. After a period of eight weeks the mean shoot length, the number of produced shoots and the number of nodes were measured.

\section{Effect of exogenously applied auxins in in vitro rooting} performance of Krymsk ${ }^{\circ} 5$ rootstock

For the rooting experiments, in vitro produced explants, approximately $1.5 \mathrm{~cm}$ in length, were transferred to the rooting substrate (DKW medium) supplemented with $20 \mathrm{~g}$ $\mathrm{L}^{-1}$ sucrose and $9 \mathrm{~g} \mathrm{~L}^{-1}$ agar). The two commonly used synthetic auxins IBA and 1-NAA were used at concentrations of $0,2.5,5,10$ and $20 \mu \mathrm{M}$ both separately and in all possible combinations. In total, 25 rooting treatments took place.

\section{Statistical analysis}

The experiment was arranged according to the completely randomized design (CRD) with four replications of five explants. The raw data were analyzed by analysis of variance (ANOVA) whereas, principal component analysis (PCA) was used in order to visualize data variance. Statistical analysis was carried out using JMP 10.0 (SAS, U.S.A.) and Statgraphics Centurion XV software for PCA and ANOVA analyses respectively. Each experiment was repeated twice. Statistically significant differences among means were detected using the LSD test at $\mathrm{p} \leq 0.05$.

\section{Results and Discussion}

\section{HPLC analysis and endogenous sugar ratio}

Krymsk $^{\circ} 5$ is a cherry rootstock of the Rosaceae family. Sorbitol was found to be the dominant sugar in softwood shoots of this cherry rootstock during late May as can be seen in Table 1. This is in agreement with the literature where sorbitol is reported to be the main sugar in Rosaceae species (Marino et al., 1993; Moing et al., 1997; Bianco and Rieger 2002; Yaseen et al., 2013). As far as the other sugars are concerned, fructose and sucrose have been found to participate equally, whereas glucose is the second most abundant sugar. Similar findings, had been reported by Ranney et al. (1991) working with 'Colt' cherry rootstock and sour cherry cv. 'Meteor'.

The Sorbitol:Sucrose ratio (SSR) has been related to environmental conditions where the plant is growing (Moing et al., 1997; Kanayama 2009). According to Moing et al. (1997) in mature leaves this ratio ranges from approximately 0.81 to 5.59 . In the present study, the ratio exceeds that found in mature leaves, probably due to different genotype studied and geographical origin as Moing et al. (1997) suggested.

\section{Effect of the sugar source on shoot proliferation}

Sugars can affect plant development in vitro, influencing plant physiology and morphogenesis. Supplementing the growth medium with the carbohydrates found endogenously in actively growing shoots resulted in insignificantly higher number of shoots and nodes produced per explant in comparison to sucrose (Table 2). Sucrose has been found to be the main sugar in the phloem sap of many species (Fuentes et al., 2000; Ahmad et al., 2007) and is used as the main carbon source in micropropagation due to its low price and high efficiency (George et al., 2008). On the other hand, Hammatt (1993) suggested that better results can be achieved when the proportions of the phloem sap sugars are used in vitro supported by the present results (Table 2).

Based on the above results, a substrate containing the endogenous sugar ratio, characterized by high concentration of sorbitol, is more efficient during the proliferation stage of Krymsk $^{\circ} 5$ instead of an exclusively containing sucrose substrate. Sorbitol efficiency on Rosaceae family species micropropagation has been long known. Sorbitol included in the substrate was superior to sucrose in pear (Kadota $e t$ al., 2001), apricot (Marino et al., 1993), apple (Moncousin et al., 1992), peach rootstock GF677 (Ahmad et al., 2007) and others, increasing in some species the number of microshoots produced (Borkowska and Szczerba, 1991; Marino et al., 1993), or shoot elongation (Marino et al., 1993). Furthermore, in the in vitro multiplication stage of 'Lapins' sweet cherry and 'Tabel Edabriz' cherry rootstock, sucrose was the least efficient carbon source while sorbitol, glucose and fructose gave better results (Ruzic et al., 2008a). On the other hand, Cheong and An (2015) studying eight different Prunus species, concluded that only for Prunus salicina and Prunus tomentosa fructose and glucose enhanced adventitious shoot induction compared to sucrose, but sorbitol was not included in the experiment. Although sorbitol seems to be the preferable sugar for some Rosaceae species in in vitro proliferation, a mixture of sugars based on the endogenously detected shoot sugar proportion has not be tested yet (according to our knowledge). Thus, the effects of the different carbon sources on explant growing during in vitro proliferation are not sufficiently studied.

Table 1. Endogenous sugar percentage in Krymsk 5 shoots during late May

\begin{tabular}{|c|c|c|c|c|c|}
\hline & \multicolumn{4}{|c|}{ Sugars } & \multirow[b]{2}{*}{$\operatorname{SSR}^{1}$} \\
\hline & Sucrose & Fructose & Glucose & Sorbitol & \\
\hline Percentage (\%) & 8 & 8 & 17 & 67 & 8.3 \\
\hline
\end{tabular}

Table 2. Effect of sugar source on shoot proliferation variables

\begin{tabular}{ccccc}
\hline Source of carbon & Shoots per explant & Shoot length $(\mathrm{cm})$ & Nodes per explant & Nodes per shoot \\
\hline Endogenous mix & $2.06 \mathrm{~b}$ & $1.28 \mathrm{a}$ & $9.45 \mathrm{~b}$ & $4.31 \mathrm{a}$ \\
Sucrose & $1.29 \mathrm{a}$ & $1.23 \mathrm{a}$ & $5.52 \mathrm{a}$ & $3.85 \mathrm{a}$ \\
\hline
\end{tabular}


Borkowska and Szczerba (1991) using a sugar mixture comprising of sucrose, glucose and fructose in equal proportions concluded that the proliferation rate was the lowest among treatments and that generally the presence of fructose in the medium decreased the number of shoots. On the contrary, Cheong and An (2015) and Rugini et al. (1987) reported that fructose can improve proliferation parameters in some species.

In the present study, the presence of fructose did not have the negative impact described by Borkowska and Szczerba (1991) indicating that both the type of sugar and the applied concentration of each sugar as well as the interactions among them can have a significant effect. Although Borkowska and Szczerba (1991) agree that fructose presence in the medium can increase shoot length of sour cherry explants, this is not confirmed by the present results, probably due to either different genotype and/or presence of other carbohydrates in higher concentrations than fructose.

\section{Effect of cytokinin treatments on shoot proliferation}

Many times the supplementation of a growth medium with only cytokinins is not sufficient to induce the formation of axillary shoots. This was observed in preliminary experiments with Krymsk 5 explants grown in DKW medium supplied only with BA (data not shown). The simultaneous presence of cytokinin, giberellin and auxin, in the nutrient substrate has proven to be more efficient for Prunus rootstocks in vitro according to Brison et al. (1995).

When the main effects of cytokinins were tested irrespective of their concentration it was found that all used adenines resulted in statistically higher shoot length than phenylureas (Table 3). Among the cytokinins tested, BA and CPPU produced the highest number of shoots per explant, resulting in 2.23 and 1.87 shoots respectively. CPPU has been found to be effective in adventitious shoot regeneration of Actinidia deliciousa cv. 'Tomuri' and 'Hayward', mulberry, avocado and raspberry (Caboni et al., 2009) and adventitious shoots formation from callus of Malus pumila (Kadota and Niim, 2003). On the other hand, BA is maybe the most used and effective cytokinin in Prunus micropropagation (Borkowska and Szczerba, 1991; Marino et al., 1993; Rossi et al., 1993; Nowak et al., 2004; Cheong and An, 2015; Wiszniewska et al., 2016) and is suggested as the preferable cytokinin for many Prunus rootstocks such as 'GF677' (Prunus amygdalus $\times$ Prunus persica) (Alanagh et al., 2010), Adesoto (Prunus insititia)
(Andreu and Marın, 2005), 'HS 314' (Prunus amygdalus $\times$ Prunus persica) (Dejampour et al., 2011), 'Fereley-Jaspi' (Prunus salicina $\times$ Prunus spinosa), 'Ferlenain-plumina' (Prunus besseyi $\times$ unknown parent) (Brison et al., 1995) etc. mTop has been found to be better than BA in Musa spp. (Escalona et al., 2003) and Pelargonium (Wojtania, 2010). Gentile et al., (2014) working with the Prunus rootstocks 'Ferdor' and 'Torinel' and Monticelli et al. (2017) working with 'Penta' and 'Myrobalan 29C' found out that mTop did not improve any further the proliferation rate compared to $\mathrm{BA}$ as has been found in the present experiment too. In the present study, Kin and $2 \mathrm{iP}$ were generally ineffective compared to BA for all the parameters measured. The same tendency has been observed in many Prunus species using Kin and $2 \mathrm{iP}$ and it might be the explanation why $2 \mathrm{iP}$ and Kin are not usually used in micropropagation of fruit species (Ruzic and Vujovic, 2008b). On the other hand, Kin has been reported to be the most suitable among BA, TDZ and $\mathrm{Z}$ for shoot multiplication of cucumber (Abu-Romman et al., 2015) indicating that the suitable cytokinin type for in vitro propagation is genotype dependent. Despite the fact that TDZ produced better results in apple shoot proliferation than adenines (Kadota et al., 2003), in the present trial it presented the lowest efficacy, indicating that Krymsk $^{\circ} 5$ prefers adenine type cytokinin compared to phenylureas.

With the aim of enabling a better and simple visual interpretation of adenine efficacy, a PCA was conducted (Fig. 1). PCA revealed that adenine cytokinins could be separated into two groups. Group I consisted of BA and characterized by high number of nodes per explant and shoot, while the rest of adenines (Kin, mTop and 2iP) comprised the second group (Group II) characterized by high shoot length. The first component of the analysis explained $38.5 \%$ of the variation and the second one an additional $33.1 \%$ that is a total of $71.6 \%$ (Fig. 1). The first component was associated with shoot number, whereas the second one with shoot length.

Medium autoclaving has no significant impact on the physical stability of all of the four adenine cytokinins assayed (Hart et al., 2016). Therefore any difference in the effectiveness among cytokinins could be partly attributed to the different metabolism of them within the plant. BA higher efficacy could be assigned to the fact that it is not a suitable substrate of cytokinin oxidase (van Staden and Crouch, 1996; Kieber and Schaller, 2004; George et al., 2008), the enzyme responsible for the endogenous cytokinin homeostasis (Schmülling et al., 2003).

Table 3. Effect of cytokinins on proliferation parameters

\begin{tabular}{|c|c|c|c|c|c|c|}
\hline \multirow{3}{*}{ Parameters } & \multicolumn{6}{|c|}{ Cytokinin } \\
\hline & \multicolumn{4}{|c|}{ Adenines } & \multicolumn{2}{|c|}{ Phenylureas } \\
\hline & BA & $2 \mathrm{iP}$ & mTop & Kin & TDZ & $\mathrm{CPPU}$ \\
\hline Shoots per explant & $2.23 \mathrm{c}$ & $0.72 \mathrm{ab}$ & $0.98 \mathrm{~b}$ & $0.57 \mathrm{a}$ & $0.4 \mathrm{a}$ & $1.87 \mathrm{c}$ \\
\hline Shoot length $(\mathrm{cm})$ & $1.16 \mathrm{~b}$ & $1.49 \mathrm{c}$ & $1.41 \mathrm{bc}$ & $1.37 \mathrm{bc}$ & $0.56 \mathrm{a}$ & $0.5 \mathrm{a}$ \\
\hline Nodes per explant & $8.4 \mathrm{e}$ & $3.95 \mathrm{~cd}$ & $4.9 \mathrm{~d}$ & $2.8 \mathrm{ab}$ & $2.3 \mathrm{a}$ & $3.5 \mathrm{bc}$ \\
\hline Nodes per shoot & $3.88 \mathrm{c}$ & $3.9 \mathrm{c}$ & $4.45 c$ & $2.85 \mathrm{~b}$ & $2.13 \mathrm{ab}$ & $1.86 \mathrm{a}$ \\
\hline Nodes per $\mathrm{cm}$ & $3.45 \mathrm{bcd}$ & $2.7 \mathrm{ab}$ & $3.84 \mathrm{~cd}$ & $2.16 \mathrm{a}$ & $2.84 \mathrm{abc}$ & $4.19 \mathrm{~d}$ \\
\hline
\end{tabular}

Means within the same row followed by the same letter do not differ significantly according to LSD multiple range test at $\mathrm{p} \leq 0.05$ 


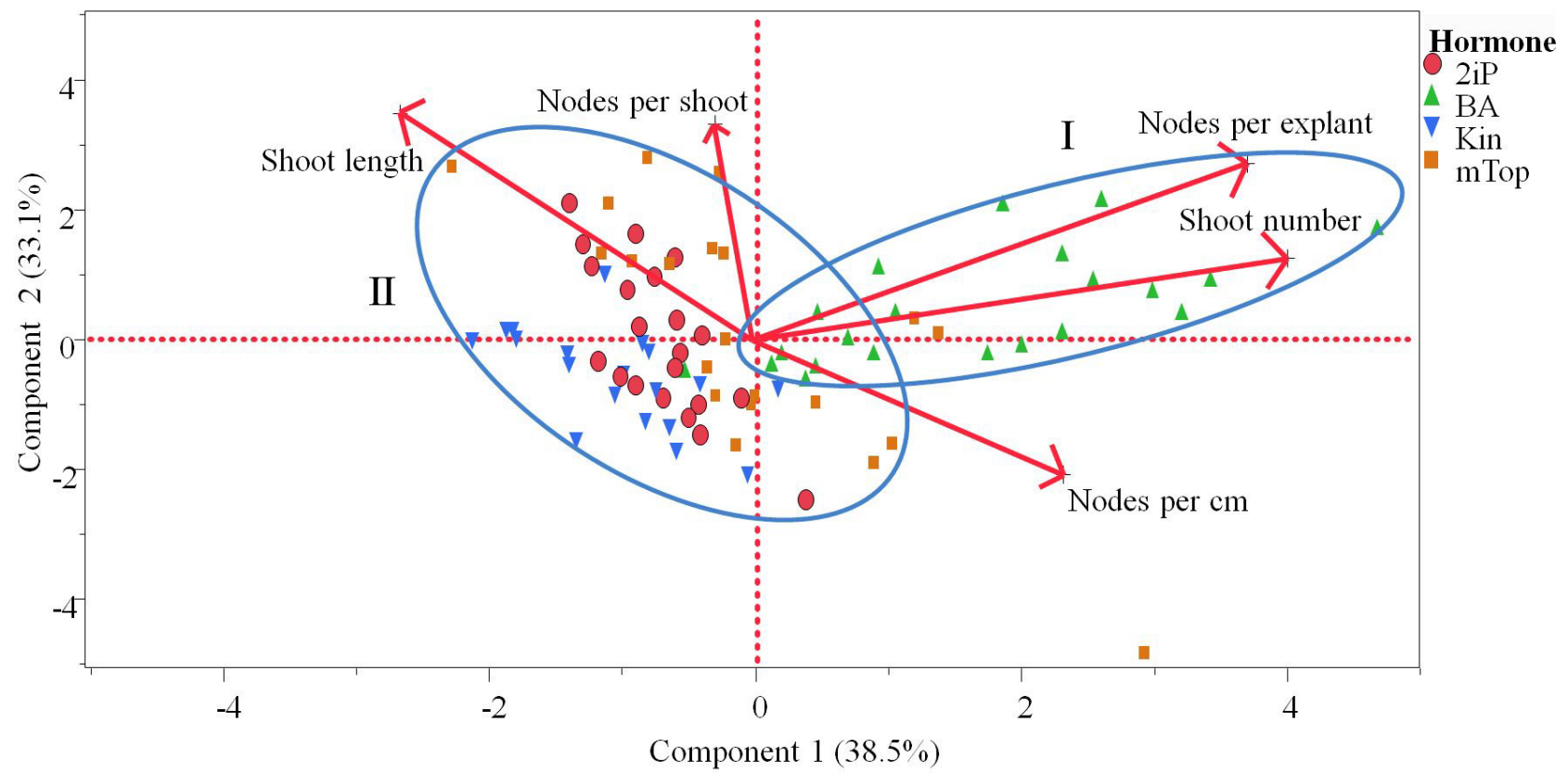

Fig. 1. Biplot of the proliferation parameters (shoot length, nodes per shoot, shoot number produced per explant, node number per explant and nodes per $\mathrm{cm}$ ) of shoots produced after adenine treatments [BA(triangle marker), Kin (reverse triangle marker), $\mathrm{mTop}$ (square marker) and 2iP (cycle marker)] on Krymsk 5 explants and adenine grouping (groups I and II).

Furthermore, some of the conjugated forms of BA produced during BA metabolism, present cytokinin activity (van Staden and Crouch, 1996; Zhang et al., 2010), extending thus its action. Moreover, BA can be characterized as the most stable among the cytokinins tested, since the stability of the aromatic side chain substituted at $\mathrm{N}^{6}$ is higher than the isoprenoid chain of $2 \mathrm{iP}$, the furan chain of Kin and the phenol chain of mTop.

When the effect of each cytokinin in equimolar concentration was tested, it was evident that the maximum number of shoots per explant was achieved by the use of 9.6 $\mu \mathrm{M} \mathrm{BA}$ (3.6 shoots) (Fig. 2). Increasing the concentration of all three BA, mTop and TDZ resulted in increased number of shoots per explant. Higher concentrations of BA have been used in in vitro culture of other Prunus species, indicating that a higher concentration of $\mathrm{BA}$ i.e. higher than $9.6 \mu \mathrm{M}$ could be effective for Krymsk 5 too (Tiwari et al., 2001; Kodota et al., 2003; Alanagh et al., 2010; Gonbad et al., 2014; Fallahpour et al., 2016).

As far as the shoot length is concerned, adenines produced longer shoots than phenylureas, as indicated in Fig. 3. Kin, $2 \mathrm{iP}$ and $\mathrm{mTop}$ addition in the medium resulted in high shoot length, followed by BA. Similar results have been reported by other researchers working with either cherry cultivars or apricot ones (Murai et al., 1997; Ruzic and Vujovic, 2008b), while according to Fallahpour et al. (2016) in GiSelA 5 rootstock the highest shoot length can be obtained by the simultaneous addition of BA and Kin in the medium. CPPU as well as TDZ resulted in decreased shoot length, irrespective of the concentration used, in agreement with Huetteman and Preece (1993) and Pruski et al. (2005) who found that TDZ inhibited shoot elongation and retarded shoot growth in comparison to $\mathrm{BA}$, Kin and 2iP. Thus, it seems that phenylureas exhibit an inhibitory effect on shoot growth of Krymsk 5 rootstock.
As node constitutes the propagation unit for in vitro micropropagation it is important for a micropropagtaion protocol to achieve the highest number of nodes per explant, during the proliferation stage. The results suggested the $4.8 \mu \mathrm{M}$ and $9.6 \mu \mathrm{M}$ of BA were the treatments with the highest node production per explant (Fig. 4). The higher the concentration of $\mathrm{BA}$ used the higher was the number of nodes, especially between the low and medium BA concentration. The two highest $\mathrm{BA}$ concentrations resulted in the highest number of shoots per explant (Fig. 4), indicating that the increased node production is strongly related to the number of shoots of this rootstock (Fig. 1).

The maximum node number per shoot was achieved by $9.6 \mu \mathrm{M} \mathrm{mTop}$ (Fig. 5). A tendency of increased number of nodes per shoot per increased cytokinin concentration was recorded under all three $2 \mathrm{iP}, \mathrm{TDZ}$ and mTop addition, while the opposite stood for CPPU addition. This indicates that all three previous mentioned cytokinins are effective in inducing high number of nodes per shoot, but are less effective on inducing axillary shoot formation (Fig. 2). One could suggest that a combined effect of $\mathrm{BA}$ on inducing high number of shoots along with 2iP and/or TDZ and/or mTop could result in the maximum production of nodes per explants, exploiting at the same time the efficiency of $\mathrm{BA}$ on increasing shoot production and the efficiency of the other three cytokinins on increasing node formation per shoot.

On the other hand, the node number per shoot $\mathrm{cm}$, which represents the density of nodes on the shoot and indirectly the length of internode was highest under $2.4 \mu \mathrm{M}$ of mTop (Fig. 6). TDZ followed the same pattern as previously, increasing the node density as the concentration elevated (Fig. 6). The lowest density of nodes was achieved under Kin inclusion the medium, indicating that the specific cytokinin affects internode length, producing 
explants with larger internodes and easy to handle propagules.

\section{Effect of different TDZ concentrations}

TDZ has been used successfully in the in vitro propagation of various plant species stimulating shoot formation but in lower concentrations compared to

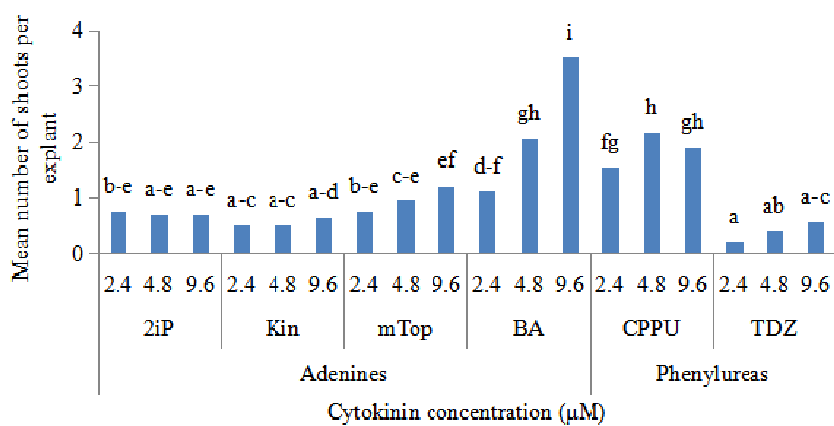

Fig. 2. Number of axillary shoots produced per explant after two months of cultivation in six different cytokinins (2iP, Kin, mTop, BA, CPPU and TDZ) and three cytokinin concentrations $(2.4 \mu \mathrm{M}, \quad 4.8 \mu \mathrm{M}$ and $9.6 \mu \mathrm{M})$. Columns followed by the same letter do not differ significantly according to the LSD multiple range test $(\mathrm{p} \leq 0.05)$

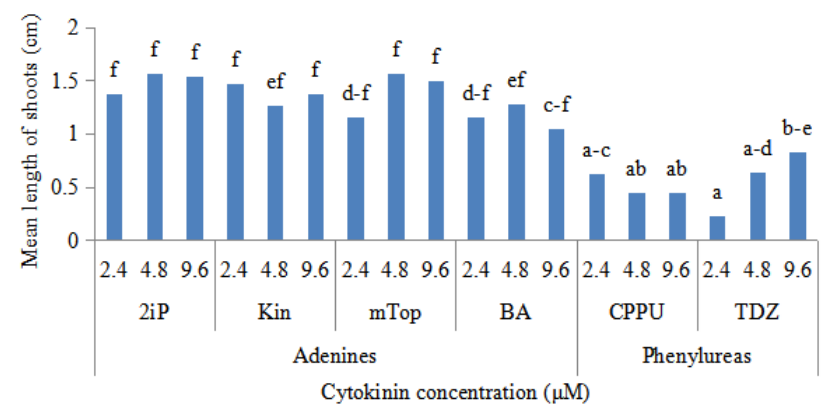

Fig. 3. Average length (in $\mathrm{cm}$ ) of axillary shoots produced per explant after two months of cultivation in six different cytokinins (2iP, Kin, mTop, BA, CPPU and TDZ) and three cytokinin concentrations $(2.4 \mu \mathrm{M}, 4.8 \mu \mathrm{M}$ and $9.6 \mu \mathrm{M})$. Columns followed by the same letter do not differ significantly according to the LSD multiple range test $(\mathrm{p} \leq 0.05)$

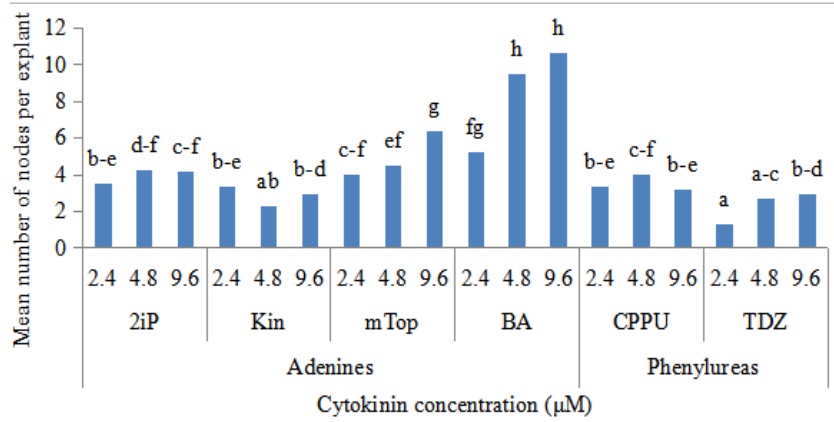

Fig. 4. Average number of nodes produced per explant after two months of cultivation in six different cytokinins (2iP, Kin, mTop, BA, CPPU and TDZ) and three cytokinin concentrations $(2.4 \mu \mathrm{M}, \quad 4.8 \mu \mathrm{M}$ and $9.6 \mu \mathrm{M})$. Columns followed by the same letter do not differ significantly according to the LSD multiple range test $(\mathrm{p} \leq 0.05)$ adenines (Huetteman and Preece, 1993). When used in high concentrations, i.e. concentrations used for the adenine cytokinins, TDZ may cause a series of undesirable reactions such as somatic embryos development, callus formation, shoot growth inhibition (Huetteman and Preece, 1993; Guo et al., 2011), shoot hyperhydricity and fasciation (Guo et al., 2011). According to Huetteman and Preece (1993) in order to define the best TDZ concentration, preliminary experiments should be conducted with equimolar concentrations between adenines and TDZ as well as lower level concentrations of TDZ. Since TDZ in the present experiment was the least effective cytokinin for the in vitro propagation of Krymsk ${ }^{\circledR}$, lower concentrations were also used, in order to assess their effects. Thus, TDZ was also tested at $1 / 10^{\text {th }}$ of the concentrations initially used, ranging from $0.24 \mu \mathrm{M}$ to $9.6 \mu \mathrm{M}$ (Table 4). There were not any significant differences for the parameters measured except for shoot length, where the $0.48 \mu \mathrm{M}$ treatment resulted in the maximum length. In general, lower concentrations resulted in longer shoots confirming that high TDZ concentration may inhibit shoot growth (Huetteman and Preece, 1993; Guo et al., 2011). Callogenesis was also observed but there were not significant differences among the different concentrations (data not shown). It seems that Krymsk $^{\oplus} 5$ responds better to the presence of adenine

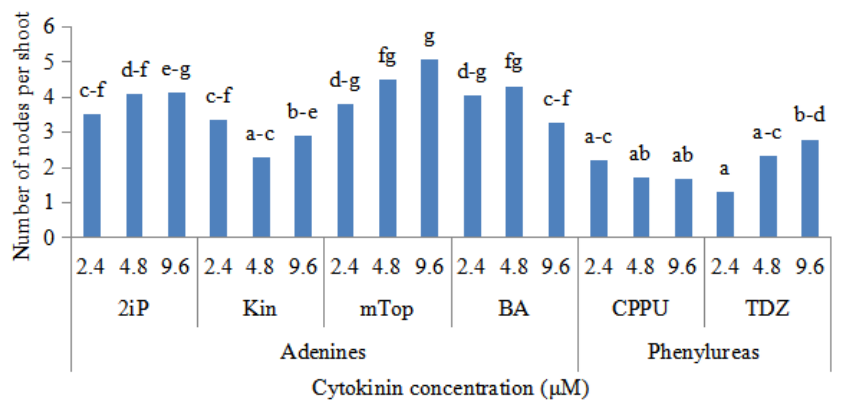

Fig. 5. Average number of nodes per shoot produced after two months of cultivation in six different cytokinins (2iP, Kin, mTop, BA, CPPU and TDZ) and three cytokinin concentrations $(2.4 \mu \mathrm{M}, \quad 4.8 \mu \mathrm{M}$ and $9.6 \mu \mathrm{M})$. Columns followed by the same letter do not differ significantly according to the LSD multiple range test $(\mathrm{p} \leq 0.05)$

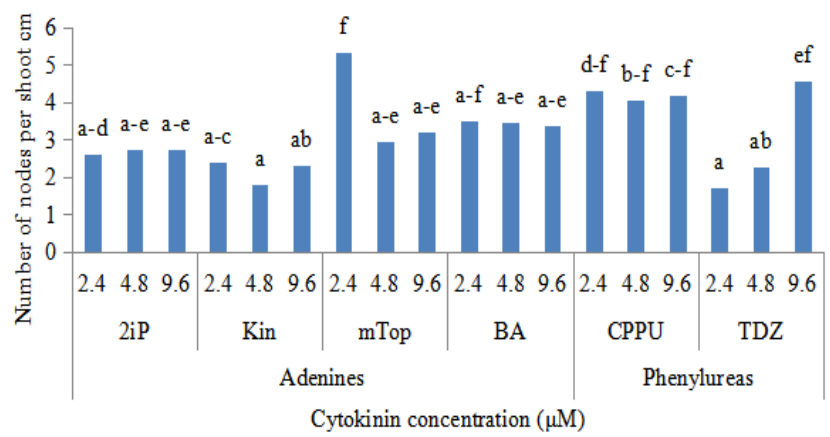

Fig. 6. Average number of nodes per $\mathrm{cm}$ of shoot produced after two months of cultivation in six different cytokinins ( 2iP, Kin, mTop, BA, CPPU and TDZ) and three cytokinin concentrations $(2.4 \mu \mathrm{M}, \quad 4.8 \mu \mathrm{M}$ and $9.6 \mu \mathrm{M})$. Columns followed by the same letter do not differ significantly according to the LSD multiple range test $(\mathrm{p} \leq 0.05)$ 
Table 4. Effect of different TDZ concentrations on proliferation variables

\begin{tabular}{ccccccc}
\hline \multirow{2}{*}{ Parameters } & \multicolumn{7}{c}{ TDZ $(\mu \mathrm{M})$} & & \\
\cline { 2 - 7 } & 0.24 & 0.48 & 0.96 & 2.4 & 0.8 & 9.6 \\
\hline Shoots per explant & $0.64 \mathrm{a}$ & $0.64 \mathrm{a}$ & $0.57 \mathrm{a}$ & $0.22 \mathrm{a}$ & $0.57 \mathrm{a}$ \\
Shoot length $(\mathrm{cm})$ & $1.11 \mathrm{bc}$ & $1.54 \mathrm{c}$ & $0.87 \mathrm{a}-\mathrm{c}$ & $0.23 \mathrm{a}$ & $0.63 \mathrm{ab}$ & $0.83 \mathrm{a}-\mathrm{c}$ \\
Nodes per explant & $3.00 \mathrm{a}$ & $3.21 \mathrm{a}$ & $2.74 \mathrm{a}$ & $1.29 \mathrm{a}$ & $2.67 \mathrm{a}$ & $2.9 \mathrm{a}$ \\
Nodes per shoot & $3.00 \mathrm{a}$ & $3.21 \mathrm{a}$ & $2.74 \mathrm{a}$ & $1.29 \mathrm{a}$ & $2.31 \mathrm{a}$ & $2.80 \mathrm{a}$ \\
Nodes per cm & $2.48 \mathrm{a}$ & $1.95 \mathrm{a}$ & $4.5 \mathrm{a}$ & $1.7 \mathrm{a}$ & $2.25 \mathrm{a}$ & $4.56 \mathrm{a}$ \\
\hline
\end{tabular}

Means within the same row followed by the same letter do not differ significantly according to the LSD multiple range test ( $\mathrm{p} \leq 0.05)$

Table 5. Main effects of auxin type and their interaction on rooting variables

\begin{tabular}{cccc}
\hline Auxin & Rooted explants $(\%)$ & Number of roots & Length of roots $(\mathrm{cm})$ \\
\hline Control & $40 \mathrm{a}$ & $6.8 \mathrm{ab}$ & $0.24 \mathrm{a}$ \\
IBA & $55 \mathrm{a}$ & $4.55 \mathrm{a}$ & $0.32 \mathrm{a}$ \\
1-NAA & $80.4 \mathrm{~b}$ & $6.15 \mathrm{ab}$ & $0.35 \mathrm{a}$ \\
IBA*1-NAA & $70.3 \mathrm{~b}$ & $7.15 \mathrm{~b}$ & $0.31 \mathrm{a}$ \\
\hline
\end{tabular}

Means within the same column followed by the same letter do not differ significantly according to the LSD multiple range test $(\mathrm{p} \leq 0.05)$

Table 6. Effect of auxin combinations on rooting variables

\begin{tabular}{|c|c|c|c|c|c|}
\hline & \multicolumn{2}{|c|}{ Auxin } & \multirow{2}{*}{ Rooted explants (\%) } & \multirow{2}{*}{ Number of roots } & \multirow{2}{*}{ Length of roots $(\mathrm{cm})$} \\
\hline & IBA & NAA & & & \\
\hline \multirow{25}{*}{ 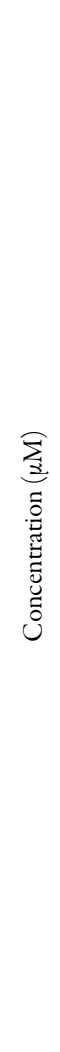 } & 0 & 0 & $40 \mathrm{ab}$ & $6.8 \mathrm{~b}-\mathrm{f}$ & $0.23 \mathrm{a}-\mathrm{c}$ \\
\hline & 0 & 2.5 & $90 \mathrm{fg}$ & $5.9 \mathrm{a}-\mathrm{f}$ & $0.44 \mathrm{~d}-\mathrm{g}$ \\
\hline & 0 & 5 & $67 \mathrm{~b}-\mathrm{g}$ & $3.3 \mathrm{a}$ & $0.19 \mathrm{a}$ \\
\hline & 0 & 10 & $90 \mathrm{fg}$ & $8.2 \mathrm{f}$ & $0.55 \mathrm{fg}$ \\
\hline & 0 & 20 & $75 \mathrm{~d}-\mathrm{g}$ & $7.1 \mathrm{c}-\mathrm{f}$ & $0.22 \mathrm{ab}$ \\
\hline & 2.5 & 0 & $50 \mathrm{a}-\mathrm{d}$ & $4.9 \mathrm{a}-\mathrm{e}$ & $0.23 \mathrm{a}-\mathrm{c}$ \\
\hline & 5 & 0 & $45 \mathrm{a}-\mathrm{c}$ & $3.6 \mathrm{ab}$ & $0.61 \mathrm{~g}$ \\
\hline & 10 & 0 & $57 \mathrm{a}-\mathrm{e}$ & $4.8 \mathrm{a}-\mathrm{d}$ & $0.16 a$ \\
\hline & 20 & 0 & $68 \mathrm{~b}-\mathrm{g}$ & $4.9 \mathrm{a}-\mathrm{e}$ & $0.28 \mathrm{a}-\mathrm{d}$ \\
\hline & 2.5 & 2.5 & $32 \mathrm{a}$ & $5.3 \mathrm{a}-\mathrm{f}$ & $0.19 a$ \\
\hline & 5 & 5 & $43 \mathrm{ab}$ & $4.4 \mathrm{a}-\mathrm{c}$ & $0.15 \mathrm{a}$ \\
\hline & 10 & 10 & $85 \mathrm{e}-\mathrm{g}$ & $7.6 \mathrm{c}-\mathrm{f}$ & $0.18 \mathrm{a}$ \\
\hline & 20 & 20 & $85 \mathrm{e}-\mathrm{g}$ & $7.6 \mathrm{c}-\mathrm{f}$ & $0.18 \mathrm{a}$ \\
\hline & 2.5 & 5 & $83 \mathrm{e}-\mathrm{g}$ & $7.5 \mathrm{c}-\mathrm{f}$ & $0.47 \mathrm{~d}-\mathrm{g}$ \\
\hline & 2.5 & 10 & $67 \mathrm{~b}-\mathrm{g}$ & $5.7 \mathrm{a}-\mathrm{f}$ & $0.27 \mathrm{a}-\mathrm{d}$ \\
\hline & 2.5 & 20 & $73 \mathrm{c}-\mathrm{g}$ & $7.6 \mathrm{c}-\mathrm{f}$ & $0.22 \mathrm{ab}$ \\
\hline & 5 & 2.5 & $50 \mathrm{a}-\mathrm{d}$ & $8.3 \mathrm{f}$ & $0.40 \mathrm{~b}-\mathrm{f}$ \\
\hline & 5 & 10 & $85 \mathrm{e}-\mathrm{g}$ & $7.3 c-f$ & $0.23 \mathrm{a}-\mathrm{c}$ \\
\hline & 5 & 20 & $82 \mathrm{e}-\mathrm{g}$ & $8.0 \mathrm{~d}-\mathrm{f}$ & $0.29 \mathrm{a}-\mathrm{d}$ \\
\hline & 10 & 2.5 & $63 \mathrm{~b}-\mathrm{f}$ & $6.8 \mathrm{~b}-\mathrm{f}$ & $0.32 \mathrm{a}-\mathrm{e}$ \\
\hline & 10 & 5 & $58 \mathrm{a}-\mathrm{d}$ & $6.1 \mathrm{a}-\mathrm{f}$ & $0.22 \mathrm{ab}$ \\
\hline & 10 & 20 & $63 \mathrm{~b}-\mathrm{f}$ & $8.1 \mathrm{ef}$ & $0.40 \mathrm{~b}-\mathrm{f}$ \\
\hline & 20 & 2.5 & $75 \mathrm{~d}-\mathrm{g}$ & $8.5 \mathrm{f}$ & $0.48 \mathrm{~d}-\mathrm{g}$ \\
\hline & 20 & 5 & $95 \mathrm{~g}$ & $8.2 \mathrm{f}$ & $0.46 \mathrm{~d}-\mathrm{g}$ \\
\hline & 20 & 10 & $85 \mathrm{e}-\mathrm{g}$ & $7.3 c-f$ & $0.30 \mathrm{a}-\mathrm{d}$ \\
\hline
\end{tabular}

Means within the same column followed by the same letter do not differ significantly according to the LSD multiple range test ( $\mathrm{p} \leq 0.05)$

cytokinins in the medium than phenylureas, which has been observed in other species too (Murai et al., 1997; Ružić and Vujović, 2008; Rafique and Anis, 2014).

\section{Effect of auxin treatments on rooting}

From the analysis of auxin type main effects it was concluded that the highest rooting percentage was achieved by the addition of 1-NAA the medium, reaching $80 \%$ (Table 5). IBA inclusion did not induce a high rooting percentage, as this was similar to that achieved under control condition (no auxin in the medium). Similar results have been found by Tang et al., (2001) who concluded that NAA treated explants of 'Napoleon' and 'Beutel Spacher Rexelle' cultivars rooted in higher percentage in than the IBA treated ones. The combination of the two auxins resulted also in high rooting percentages.

Thus, it seems that Krymsk 5 responds better to the presence of 1-NAA in the medium, despite the fact that for 
many Prunus species IBA has been used as the preferable auxin for rooting induction (Kalinia and Brown 2007; Dejampour et al., 2011; Sadeghi et al., 2015) while sometimes 1-NAA has been found to be ineffective on inducing rooting (Dejampour et al., 2011). Working on micropropagation of olive, Canas (1988) concluded that IBA is more efficient for some cultivars whereas 1-NAA for others. It is clear then that the genotype greatly influences explant response to the presence of a specific auxin and could explain our findings with Krymsk 5 compared to those in other Prunus genotypes. This is further corroborated by Dolcet-Sanjuan et al. (2004) working with walnut, who reported that rooting response depends on many factors, among which the type of auxin used, the applied concentration, the species or even the clone of a specific species.

The number of roots is a significant factor for increased plant survival percentage during the acclimatization phase and it is considered as a qualitative trait of rooting response (Roussos et al., 1999; Dolcet-Sanjuan et al., 2004). The combination of both IBA and 1-NAA irrespective of the concentrations used, resulted in the highest number of roots while IBA alone exhibited significantly fewer roots (Table 5).

The highest root induction was achieved when $20 \mu \mathrm{M}$ of IBA and $5 \mu \mathrm{M}$ of 1 -NAA were combined, reaching $95 \%$ of rooted explants, followed by $1-\mathrm{NAA}$ alone at 2.5 and $10 \mu \mathrm{M}$ (90\%) (Table 6). Similar results, under IBA and NAA combination were achieved by Mangal et al. (2014) in in vitro rooting of olive cv. 'Frantoio' and by Roussos et al. (1999) working with jojoba. As far the root number is concerned, the highest number was obtained by the combinations $5 \mu \mathrm{M}$ IBA - $2.5 \mu \mathrm{M}$ NAA, $20 \mu \mathrm{M}$ IBA - 2.5 $\mu \mathrm{M}$ NAA, $20 \mu \mathrm{M}$ IBA $-5 \mu \mathrm{M}$ NAA, $20 \mu \mathrm{M}$ IBA $-10 \mu \mathrm{M}$ NAA and $10 \mu \mathrm{M}$ NAA, indicating that IBA and NAA may act synergistically on root elongation. Increasing IBA concentration did not increase root number, unlike the results reported by Fotopoulos and Sotiropoulos, (2005) and Fallahpour et al. (2015) in PR 204/84 and GiSelA 5 respectively. The highest root length was observed under IBA at $5 \mu \mathrm{M}$ and the lowest under the equimolar addition of both auxins at $5 \mu \mathrm{M}$. Hossini et al. (2010) working on GiSelA $^{\circ} 6$ reported that increased IBA concentration caused a significant shortening of roots similar to that observed in the present trial. During the acclimatization stage under mist approximately $90 \%$ of rooted explants survived and continued growing.

\section{Conclusions}

The first protocol for efficient in vitro propagation of the cherry rootstock Krymsk 5 was established in the present study. During the proliferation stage the DKW nutrient medium, adjusted at $\mathrm{pH} 5.8$, supplied with $30 \mathrm{~g} \mathrm{~L}^{-1}$ of sugars $\left(2.4 \mathrm{~g} \mathrm{~L}^{-1}\right.$ sucrose, $2.4 \mathrm{~g} \mathrm{~L}^{-1}$ fructose, $5.2 \mathrm{~g} \mathrm{~L}^{-1}$, glucose and $20 \mathrm{~g} \mathrm{~L}^{-1}$ sorbitol), $9 \mathrm{~g} \mathrm{~L}^{-1}$ agar, $9.6 \mu \mathrm{M} \mathrm{BA}, 0.7$ $\mu \mathrm{M} \mathrm{GA}_{3}$ and $0.5 \mu \mathrm{M}$ NAA resulted in a high proliferation rate. During the rooting stage, the DKW medium adjusted to $\mathrm{pH} 5.8$ and supplied with $20 \mathrm{~g} \mathrm{~L}^{-1}$ sucrose, $9 \mathrm{~g} \mathrm{~L}^{-1}$ agar and an auxin combination of $5 \mu \mathrm{M}$ IBA and $20 \mu \mathrm{M}$ NAA resulted in the optimum rooting response. The present findings can be successfully utilized in both commercial and experimental large scale clonal in vitro propagation of this rootstock.

\section{Acknowledgements}

At this point we would like to thank Janssen Brothers Nurseries (Netherlands) and Paul Janssen in personal for providing us with the Krymsk 5 mother plants.

\section{References}

Abu-Romman SM, Al-Hadid KA, Arabiyyat AR (2015). Kinetin is the most effective cytokinin on shoot multiplication from cucumber. The Journal of Agricultural Science 7:159-165.

Ahmad T, Akhtar Abbasi N, Hafiz IA, Ali A (2007). Comparison of sucrose and sorbitol as main carbon energy source in morphogenesis of peach rootstock GF-677. Pakistan Journal of Botany 39:12641275.

Akhtar G, Jaskani MJ, Sajjad Y, Akram A (2016). Effect of antioxidants, amino acids and plant growth regulators on in vitro propagation of Rosa centifolia. Iranian Journal of Biotechnology 14:e1152.

Alanagh EN, Garoosi GA, Haddad R(2010). The effect of PGRs on in vitro shoot multiplication of GF677 hybrid (Prunus persica $\times$ P. amygdalus) rootstock on GNH medium. Iranian Journal of Genetics and Plant Breeding 1:3443.

Andreu P, Marin JA (2005). In vitro culture establishment and multiplication of the Prunus rootstock 'Adesoto 101' (P. insititia L.) as affected by the type of propagation of the donor plant and by the culture medium composition. Scientia Horticulturae 106:258-267.

Bianco RL, Rieger M (2002). Partitioning of sorbitol and sucrose catabolism within peach fruit. Journal of the American Society for Horticultural Science 127:115-121.

Borkowska B, Szczerba J (1991). Influence of different carbon sources on invertase activity and growth of sour cherry (Prunus cerasus L.) shoot cultures. Journal of Experimental Botany 42:911-915.

Brison M, de Boucauda MT, Dosbab F (1995). Cryopreservation of in vitro grown shoot tips of two interspecific Prunus rootstocks. Plant Science 105:235-242.

Caboni E, Biasi R, Delia G, Tonelli M (2009). Effect of CPPU on in vitro axillary shoot proliferation and adventitious shoot regeneration in kiwifruit. Plant Biosystems 143:456-461.

Canas LA (1988). In vitro culture of the olive tree (Olea europaea L.): present aspects and prospects. Bulletin de la Société botanique de France 135:263-277.

CheongEJ, An C (2015). Effect of carbohydrates on in vitro shoot growth of various Prunus species. Korean Journal of Plant Resources 28:357-362.

D'Angeli S, Lauri P, Caboni E, Dewitte W, Van Onckelen H (2001). Factors affecting in vitro shoot formation from vegetative shoot apices of apple and relationship between organogenic response and cytokinin localisation. Plant Biosystems 135:95-100.

De Klerk G-J, Brugge JT, Marinova S (1997). Effectiveness of indoleacetic acid, indolebutyric acid and naphthaleneacetic acid during adventitious 
160

root formation in vitro in Malus 'Jork 9'. Plant Cell Tissue and Organ Culture 49:39-44.

Dejampour J, Majidi I, Khosravi S, Farhadi S, Shadmehr A (2011). In vitro propagation of HS314 rootstock (Prunus amygdalus $\times P$. persica). HortScience 46:928-931.

Denaxa N-K, Vemmos SN, Roussos PA (2012). The role of endogenous carbohydrates and seasonal variation in rooting ability of cuttings of an easy and a hard to root olive cultivars (Olea europaea L.). Scientia Horticulturae 143:19-28.

Dolcet-Sanjuan R, Claveria E, Gruselle R, Meier-Dinkel A, Jay-Allemand C, Gaspar T (2004). Practical factors controlling in vitro adventitious root formation from walnut shoot microcuttings. Journal of the American Society for Horticultural Science 129:198-203.

Dorić D, Ognjanov V, Ljubojević M, Barać G, Dulić J, Pranjić A, Dugalić K (2014). Rapid propagation of sweet and sour cherry rootstock. Notulae Botanicae Horti Agrobotanici Cluj-Napoca 42:488-494.

Escalona M, Cejas I, Gonzalez-Olmedo J, Capote I, Roels S, Canal MJ, Rodriguez R, Sandoval J, Debergh P (2003). The effect of meta-topolin on plantain propagation using a temporary immersion bioreactor. InfoMusa 12:28-30.

Escobar-Gutiérrez AJ, Gaudillére J-P (1994). Variability in Sorbitol: Sucrose ratios in mature leaves of different peach cultivars. Journal of the American Society for Horticultural Science 119:321-324.

Fallahpour M, Miri SM, Bouzari N (2015). In vitro propagation of 'Gisela 5' rootstock as affected by mineral composition of media and plant growth regulators. Journal of Horticultural Research 23:57-64.

Fotopoulos S, Sotiropoulos E (2004). In vitro propagation of the peach rootstock: the effect of different carbon sources and types of sealing material on rooting. Biologia Plantarum 48:629-631.

Fotopoulos S, Sotiropoulos TE (2005). In vitro rooting of PR 204/84 rootstock (Prunus persica $\times P$. amygdalus) as influenced by mineral concentration of the culture medium and exposure to darkness for period. Agronomy Research 3:3-8.

Fuentes SRL, Calheiros MBP, Manetti-Filho J, Vieira LGE(2000). The effects of silver nitrate and different carbohydrate sources on somatic embryogenesis in Coffea canephora. Plant Cell Tissue and Organ Culture 60:5-13.

Gentile A, Jaquez Gutierrez M, Martinez J, Frattarelli A, Nota P, Caboni E (2014). Effect of meta-Topolin on micropropagation and adventitious shoot regeneration in Prunus rootstocks. Plant Cell Tissue and Organ Culture 118:373-381.

George EF, Hall MA, Klerk GJD (2008). Plant Propagation by Tissue Culture. Springer, Netherlands.

Godoy S, Tapia E, Seit P, Andrade D, Sánchez E, Andrade P, Almeida AM, Prieto $H$ (2017). Temporary immersion systems for the mass propagation of sweet cherry cultivars and cherry rootstocks: development of a micropropagation procedure and effect of culture conditions on plant quality. In Vitro Cellular \& Developmental Biology-Plant 53:494504.

Gonbad RA, Sinniah UR, Aziz MA, Mohamad R (2014). Influence of cytokinins in combination with $\mathrm{GA}_{3}$ on shoot multiplication and elongation of tea clone Iran 100 (Camellia sinensis (L.) O. Kuntze). The Scientific World Journal 5:149-168.
Guo B,Zeb A, Abbasi BH,Zeb A, Xu LL, WeiYH(2011). Thidiazuron: A multi-dimensional plant growth regulator. African Journal of Biotechnology 10:8984-9000.

Hammatt N (1993). Micropropagation offastigiate bird cherry (Prunuspadus L.) and adventitious shoot formation from leaves. Journal of Horticultural Science 68:975-981.

Hart DS, Keightley A, Sappington D, Nguyen PTM, Chritton C, Seckinger GR, Torres KC (2016).Stability of adenine-based cytokinins in aqueous solution. In Vitro Cellular \& Developmental Biology-Plant 52:1-9.

Hossini AD, Moghadam EG, Anahid S (2010). Effects of media cultures and plant growth regulators in micropropagation of Gisela 6 rootstock. Annals of Biological Research 1:135-141.

Huetteman CA, Preece JE (1993). Thidiazuron: a potent cytokinin for woody plant tissue culture. Plant Cell Tissue and Organ Culture 33:105-119.

Kadota M, Imizu K, Hirano T (2001). Double-phase in vitro culture using sorbitol increases shoot proliferation and reduces hyperhydricity in Japanese pear.Scientia Horticulturae 89:207-215.

Kadota M, Niim Y (2003). Effects of cytokinin types and their concentrations on shoot proliferation and hyperhydricity in in vitro pear cultivar shoots. Plant Cell Tissue and Organ Culture 72:261-265.

Kalinina A, Brown DCW (2007). Micropropagation of ornamental Prunus spp. and GF305 peach, a Prunus viral indicator. Plant Cell Reports 26:927-935.

Kanayama Y (2009). Physiological roles of polyols in horticultural crops. Journal of the Japanese Society for Horticultural Science 78:158-168.

KieberJJ, Schaller GE (2004). Cytokinins. The Arabidopsis Book 12:e168.

Long LE, Kaiser C (2010). Sweet Cherry Rootstocks for the Pacific Northwest. PNW 619.

Maas FM, Balkhoven-Baart J, van der Steeg PAH (2014) Evaluation of Krymsk 5 (VSL-2) and Krymsk 6 (LC-52) as rootstocks for sweet cherry 'Kordia'. Acta Horticulture 1058:531-536.

Mangal M, Sharma M, KumarS (2014). In vitro regeneration in olive (Olea europaea L.) cv. 'Frontio' from nodal segments. Indian Journal of Experimental Biology 52:912-916.

Marino G, Bertazza G, Magnanini E, Doro Altan A (1993). Comparative effects of sorbitol and sucrose as main carbon energy sources in micropropagation of apricot. Plant Cell Tissue and Organ Culture 34:235-244.

Moing A, Langlois N, Svanella L, Zanetto A, Gaudillère J-P (1997). Variability in Sorbitol:Sucrose ratio in mature leaves of different Prunus species.Journal of the American Society for Horticultural Science 122:83-90.

Moncousin C, Ribaux M, O’RourkeJO, Gavillet S (1992). Effects of type of carbohydrate during proliferation and rooting of microcuttings of Malus 'Jork 9'. Agronomie 12:775-781.

MonticelliS, Gentile A, Frattarelli A, Caboni E (2017). Effects of the natural cytokininmeta-Topolin on in vitro shoot proliferation and acclimatization of Prunus spp. Acta Horticulture 1155:375-380.

Murai Y, Harada H, Yamashita H (1997). In vitro propagation of apricot (Prunus armeniaca L.) cv. 'Bakuoh junkyou'. Journal of the Japanese Society for Horticultural Science 66:475-480. 
Nacheva L, Gercheva P (2009). Micropropagation of Gisela 5 (cherry dwarf rootstock): The effect of the type and the concentration of the carbohydrates in the nutrient medium. Acta Horticulture 825:261268.

Nowak B, Miczynski K, Hudy L (2004). Sugar uptake and utilisation during adventitious bud differentiation on in vitro leaf explants of 'Wegierka Zwykta' plum (Prunus domestica). Plant Cell Tissue and Organ Culture 76:255-260.

Pruski K, Astatkie T, Nowak J (2005). Tissue culture propagation of Mongolian cherry (Prunus fruticosa) and Nanking cherry (Prunus tomentosa). Plant Cell Tissue and Organ Culture 82:207-211.

Rafique A, Anis M (2014). Rapid in vitro propagation system through shoot tip cultures of Vitex trifolia L. Physiology and Molecular Biology of Plants 20:385-392.

Ranney TG, Bassuk NL, Whitlow TH (1991). Osmotic Adjustment and Solute Constituents in Leaves and Roots of Water-stressed Cherry (Prunus) trees. Journal of the American Society for Horticultural Science 116:684-688.

Rossi F, Baraldi R, Facini O, Lercari B (1993). Photomorphogenic effects on in vitro rooting of Prunus roostock GF 655-2. Plant Cell Tissue and Organ Culture 32:145-151.

Roussos PA, Pontikis CA (2002). In vitro propagation of olive (Olea europaea L.) cr. Koroneiki. Plant Growth Regulators 37:295-304.

Roussos PA, Tolia-Marioli A, Pontikis CA, Kotsias D (1999). Rapid multiplication of jojoba seedlings by in vitro culture. Plant Cell Tissue and Organ Culture 57:133-137.

Rugini E, Tarini P, Rossodivita ME (1987). Control of shoot vitrification of almond and olive grown in vitro. Acta Horticulture 212:177-183.

Ružić DjV, Lazic T, Cerovic R (2008). Micropropagation of some Prunus and Pyrus genotypes in vitro as affected by different carbon sources. Acta Horticulture 795:413-418.

Ružić DjV, Vujović TI (2008). The effects of cytokinin types and their concentration on in vitro multiplication of sweet cherry cv. 'Lapins' (Prunus avium L). Horticultural Science-Prague 35:12-21.

Sadeghi F, Yadollahi A, Jafarkhani Kermani M, Eftekhari M (2015). Optimizing culture media for in vitro proliferation and rooting of Tetra (Prunus empyrean) rootstock. Journal of Genetic Engineering and Biotechnology 13:19-23.
Schmülling T, Werner T, Riefler M, Krupková E, Bartrina y Manns I (2003). Structure and function of cytokinin oxidase/dehydrogenase genes of maize, rice, Arabidopsis and other species. Journal of Plant Research 116:241-252.

Tang H, Ren Z, Reustle G, Krezal G (2001). Plant regeneration from leaves of sweet and sourcherry cultivars. Scientia Horticulturae 93:235-244.

Tiwari V, Tiwari KN, Singh BD (2001). Comparative studies of cytokinins on in vitro propagation of Bacopa monniera. Plant Cell Tissue and Organ Culture 66:9-16.

van Staden J, Crouch NR (1996). Benzyladenine and derivatives - their significance and interconversion in plants. Plant Growth Regulators 19:153-175.

Webster AD (1993). New dwarfing rootstocks for apple, pear, plum and sweet cherry-A briefreview. Acta Horticulturae 349:145-153.

Wiszniewska A, Nowak B, Kotton A, Sitek E, Grabski K, Dziurka M, Dhugosz-Grochowska O, Dziurka K, Tukaj Z (2016). Rooting response of Prumus domestica L. microshoots in the presence of phytoactive medium supplements. Plant Cell Tissue and Organ Culture 125:163176.

Wojtania A (2010). Effect of meta-topolin on in vitro propagation of Pelargonium $\times$ hortorum and Pelargonium $\times$ hederaefolium cultivars. Acta Societatis Botanicorum Poloniae 79:101-106.

Yancheva S, Kondakova V (2016). Plant Tissue Culture Technology: Present and Future Development In: Pavlov A, Bley T (Eds.) Bioprocessing of plant in vitro systems, Reference Series in Phytochemistry.Springer International Publishing AG.

Yaseen M, Ahmad T, Sablok G, Standardi A, Hafiz IA (2013). Review: role of carbon sources for in vitro plant growth and development. Molecular Biology Reports 40:2837-2849.

Zhang H, Horgan KJ, Reynolds PHS,Jameson PE (2010). 6-Benzyladenine metabolism during reinvigoration of mature Pinus radiata buds in vitro. Tree Physiology 30:514526. 